\title{
Seroprevalence of culicoides-borne disease in cattle in European Turkey"
}

\author{
Taner KARAOĞLU ${ }^{1}$, İran ÖZGÜNLÜK ${ }^{2}$, Başak DEMİR ${ }^{1}$, Aykut ÖZKUL ${ }^{1}$, İbrahim BURGU ${ }^{1}$ \\ ${ }^{1}$ Department of Virology, Faculty of Veterinary Medicine, Ankara University, Ankara,Turkey. ${ }^{2}$ Department of Virology, Faculty of \\ Veterinary Medicine, Harran University, Sanli Urfa, Turkey.
}

\begin{abstract}
Summary: In this research, seroprevalence of BTV serotypes (BTV-4, BTV-9, BTV-16), and occurrence of Akabane and Ephemeral fever viruses were investigated in 557 cattle sera collected from 21 locations in European Turkey (Thrace). Virus neutralization test was used to discriminate antibody response against BTV serotypes while commercial blocking-ELISA systems were used to detect antibodies for Akabane and ephemeral fever viruses. The overall seroprevalence of BTV was recorded as 73.54\%, comprising individual percentages for BTV-4, BTV-9 and BTV-16 were $69.04 \%, 71.38 \%$ and $80.2 \%$, respectively. The seroprevalence of Ephemeral fever virus infection in Thrace varied between 2.5 and $15.3 \%$ on the province basis, whilst antibody percentage for Akabane virus was found as low as $0.14 \%$ in the study.
\end{abstract}

Key words: Akabane, bluetongue, ephemeral fever, seroprevalence.

\section{Trakya bölgesinde sığırlarda sivrisineklerle nakledilen enfeksiyonların seroprevalansı}

Özet: Trakya bölgesinde, 2003 yılında 5 ile bağlı 21 ilçe/köyden toplam 557 sığır, Mavidil, Akabane ve Ephemeral Fever enfeksiyonlarının seroprevalanslarının tespiti amacıyla random sampling metoduyla örneklendi. Serum örnekleri Mavidil virusunun 3 farklı serotipine (BTV-serotip 4, BTV-serotip 9 ve BTV-serotip 16) karşı virus nötralizasyon testine tabi tutuldu. Aynı serum örneklerine Akabane ve Ephemeral Fever virus antikorlarının tespiti için blocking ELISA testi uygulandı. Trakya bölgesinde mavi dil enfeksiyonunun seroprevalans1 \%73.54 olarak tespit edilirken, BTV serotip-4 \%69.04, BTV serotip-9 \%71.38, BTV serotip-16 ise $\% 80.2$ olarak saptand. Akabane enfeksiyonunun seroprevalansı Trakya bölgesinde \%0.14 olarak belirlenirken, Ephemeral fever enfeksiyonunun seroprevalansı örneklenen iller bazında \%2.5-15.3 olarak tespit edildi.

Anahtar sözcükler: Akabane, ephemeral fever, mavidil, seroprevalans.

\section{Introduction}

Bluetongue is an economically devastating and Culicoides-born disease, which is characterized by congestion, oedema and haemorrhages in wild and domestic ruminants. In addition, this virus is responsible for fetal death, congenital defects, and reproductive failure in cattle (26).

The causative agent is classified in Reoviridae family genus Orbivirus as Bluetongue virus (BTV) has 24 serotypes $(10,12,29)$. There are three major components recognised in the epidemiology of the infection such as reservoir animal, vector and climatic conditions. The most important reservoir is cattle and they can be infected rarely $(10,12)$. The viraemia lasts about 100 days in cattle (22) while only 30 days in sheep (11). Thus it is reported that cattle play an active role either in transmitting the virus or in passaging the virus to appropriate climatic condition over winter in which the vector midges are biologically in-effective $(11,22)$. It is known that the vector midges (Culicoides spp.) has approximately 1000 subspecies in tropical and subtropical regions in which proper ecologic situations have been provided for their life cycle. However, only 17 of them have directly been related to transmission of the BTV, most probably, because of their genetic predisposition (25). BTV infection of ruminants are commonly seen in most of the tropical and subtropical regions between $35^{\circ}$ south and $40^{\circ}$ north latitutes, in which Culicoides midges are extremely effective $(10,13)$. These areas are called as incursional zones and infection of ruminants usually occurs during midday of late summer or early autumn $(10,27)$.

Akabane virus (AKAV) is a Simbuvirus classified in Bunyaviridae family, genus Bunyavirus $(17,19)$. The virus is transmitted by blood sucking midges and accepted as an important cause of abortions, fetal

\footnotetext{
* This research was supported by a grant of Scientific Research Project of Ankara University, Project Nr: 2002-08-10-043
} 
mummification, still births, and various congenital malformations in ruminant species $(17,19)$. Viraemia occurs in every case and the virus can reach to fetus by transplacental spread. The most important fetal pathology is arthrogrypposis and hydranencephalie complex in affected animals $(20,21,32)$. Akabane disease is subclinical in adult cattle although causes economical losses resulted from severe decrease in reproductive performance (32).

Bovine ephemeral fever (BEF) also causes a subclinical infection in ruminant species and is characterized by fever, acute febrile reaction, stiffness, lameness and total recovery within three days. The virus that classified in rhabdoviridae family may cause abortions $(6,30)$ in female and transient sterility in males (28). The infection is mostly seen in tropical regions of Africa, subtropical and warm territories of Australia and Asia. All three infections are called as non-infectious arthropod-borne disease and blood sucking midges play role in transmission between infected and susceptible animals. Main objective of this study is to detect the seroprevalance the local serotypes (serotype 4, 9 and 16) of Bluetongue virus, and the occurrence of Akabane and Ephemeral Fever viruses in European Turkey.

\section{Materials and Methods}

\section{Serum samples}

Blood serum samples were collected randomly from 557 cattle of 21 counties and/or villages between September-October 2003. Geographical localization and number of sampled animals are given in Figure and Table 1, respectively. The serum samples were stored at $-20^{\circ} \mathrm{C}$ freezers following inactivation at $56^{\circ} \mathrm{C}$ for 30 minutes.

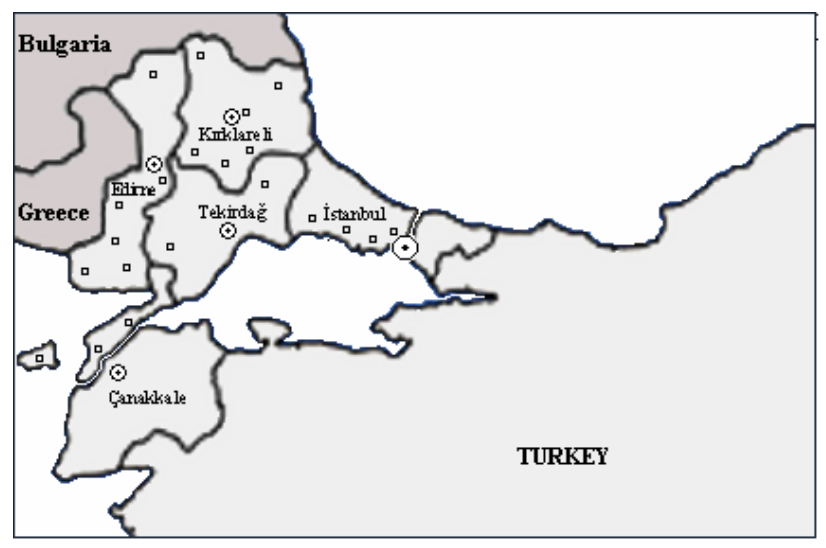

Figure 1. Geographical position of villages that have been sampled in the research. The points indicate exact location of villages.

Şekil 1. Örneklemelerin yapıldığı lokalizasyonlar (küçük kare'lerle gösterilmiştir)
Table 1. The numerical distribution of samples based on province and town.

Tablo 1. Örnekleme yapılan merkezler ve örneklenen hayvan sayıları.

\begin{tabular}{lllc}
\hline Code & Province & Town/Village & $\begin{array}{c}\text { Animal } \\
\text { number }\end{array}$ \\
\hline 01 & Canakkale & Gelibolu, Eceabat, Gokceada & 164 \\
02 & Edirne & $\begin{array}{l}\text { Lalapasa, Kesan, Uzunkopru, } \\
\text { Ipsala, Enez, Meric }\end{array}$ & 163 \\
03 & Istanbul & $\begin{array}{l}\text { Gaziosmanpasa, Silivri, } \\
\text { Catalca, B.Cekmece }\end{array}$ & 70 \\
04 & Kirklareli & $\begin{array}{l}\text { Merkez, Demirkoy, Kofcaz, } \\
\text { Luleburgaz, Vize, Babaeski }\end{array}$ & 130 \\
05 & Tekirdag & Malkara, Saray & 30 \\
Total & & & 557 \\
\hline
\end{tabular}

\section{Antibody detection}

Virus Neutralization Test (VNT): Presence of antibodies against Bluetongue virus serotypes (BTV-4, BTV-9, BTV-16) were screened using virus neutralization assay (9). Two subsets of sera were tested for their neutralizing activity against BTV serotypes. The fifty $\mu \mathrm{l}$ serum samples in duplicate were mixed with equal volume of $100 \mathrm{TCID}_{50}$ diluted BTV suspensions in 96-well plates. After neutralization at $37^{\circ} \mathrm{C}$ for $1 \mathrm{~h}, 50 \mu \mathrm{l}$ of Vero cell suspension was added all wells used of the 96-well plate. The plates were then incubated under $5 \%$ $\mathrm{CO}_{2}$ atmosphere at $37^{\circ} \mathrm{C}$ for 4 days. Then the results were assessed by microscopically monitoring of cytopathic effect.

Blocking ELISA System: For detection of AKA and $\mathrm{BEF}$ virus antibodies a commercial blocking ELISA systems (Elisabeth Mc Artur Agriculture Institute, Australia) were used. Tests were performed according to the manufacturer's directions. Briefly, serum samples were used in 1:10 and 1:8 dilutions in order to detect antibodies against AKA and BEF viruses, respectively. Test and control serums were placed into antigen-coated wells in duplicate and incubated for $1 \mathrm{~h}$. Additional $1 \mathrm{~h}$. incubation of monoclonal antibodies mixed with serum dilutions were followed by conjugate and chromogenic substrate incubations, sequentially. The results were evaluated by reading of plates in $450 \mathrm{~nm}$ spectrophotometer at the final step.

\section{Results}

Prevalence of BTV antibodies in European Turkey varied between $69.9-77.9 \%$ in province basis. The highest BTV prevalence detected was $77.9 \%$ in Edirne province, which is followed by Kirklareli (76.9\%), Canakkale (71.5\%), Istanbul (71.4\%) and Tekirdag 
(69.9\%) provinces. The seroprevalence of the BTV serotypes in Thrace were $80.2 \%, 71.38 \%$, and $69.04 \%$ for BTV-16, for BTV-9 and for BTV-4, respectively (Table 2).

Table 2. Seroprevalence of Bluetongue, Akabane and Ephemeral fever infections in Thrace.

Tablo 2. Trakya bölgesinde Mavidil, Akabane ve Ephemeral fever enfeksiyonlarının seroprevalansı.

\begin{tabular}{clccccc}
\hline & & \multicolumn{3}{c}{ Bluetongue } & \multicolumn{2}{c}{ Ephemeral } \\
Code & Province & BTV-4 & BTV-9 & BTV-16 & Akabane & Fever \\
\hline 01 & Canakkale & 71,5 & 63,4 & 79,6 & - & 2,5 \\
02 & Edirne & 65,9 & 84,3 & 83,5 & - & 15,3 \\
03 & Istanbul & 64,4 & 73,4 & 76,5 & - & 2,8 \\
04 & Kirklareli & 73,4 & 72,5 & 84,8 & 0,7 & 13 \\
05 & Tekirdag & 70,0 & 63,3 & 76,6 & - & 6,6 \\
Total & & 69,04 & 71,38 & 80,20 & 0,14 & 8,04 \\
\hline
\end{tabular}

The blocking ELISA revealed single antibody positive serum specimen for AKAV from Kirklareli, indicating low prevalences based on province $(0.7 \%)$ and Thrace $(0.14 \%)$ region.

The seroprevalence of Ephemeral fever virus was found between $2.5-15.3 \%$ in the study. The highest seroprevalence of the infection was in Edirne (15.3\%), which was followed by Kirklareli, Tekirdag, Istanbul and Canakkale, with $13 \%, 6.6 \%, 2.8 \%$, and $2.5 \%$, respectively.

\section{Discussion and Conclusion}

In this research serologic survey of some Culicoides-borne virus diseases was carried out in randomly selected cattle of European Turkey. Results revealed that prevalence of infections caused by BTV serotypes somewhat higher $(73.54 \%)$ than that of Akabane (0.14\%) and Ephemeral fever (8.04\%) virus infections in the region.

Bluetongue virus infection predominantly detected in Edirne (77.9\%), while seroprevalence of BTV in remaining provinces was between 69.9-76.9\%. This variation between provinces was accepted as traceable. On the other hand, serotypic occurence of the BT viruses showed the superiority of BTV-16 (80.2\%) and BTV-9 (71.38\%) over BTV-4 (69\%).

Two provinces (i.e. Edirne and Kirklareli) were perceived (distinguished) because of their high seroprevalence status for BTV-9 and BTV-16. On the basis of geographic features or BT occurrence data from neighboring countries, one might be postulated that
BTV-9 is predominately spread in Bulgaria, Greece and Turkey while BTV-16 is the most threaten serotype for Bulgaria and Turkey $(1,2,3,4,24)$. This speculation need to be further investigated by species distribution along the region.

Turkey has a very critical geographic location between Asia and Europe. Because of its bridge like position, European Turkey, particularly, is accepted as buffer zone in which transmission of some viral disease has been prevented by application of various central measurements in epidemiologic manner.

Common feature of the project diseases is to be transmissible under certain climate and vector conditions. Some regions of Turkey seem to have proper conditions for these infections. Wind streams coming from neighboring countries in Mediterranean basin and Middle East may cause passively transport of the vector Culicoides spp. so that new serotypes of the BTV may be acquired by the mentioned countries.

Bluetongue is an economically important infection of ruminants that causes serious decreases in reproductive ability, abortions and congenital malformations (26). Culicoides spp. responsible of transmitting project disease have been investigated in Turkey and 57 specieses of them have previously been identified by Dik (7) Mellor et al. (23) have identified 13 Culicoides spp in Southern, Southeastern and Western Turkey in which congenitally deformed calf births have been reported during the same period. They also reported seroprevalence of bluetongue, AKA and BEF viruses in cattle of the region as $2.3 \%, 12.3 \%$ and $9.2 \%$, respectively, using the competative ELISA.

After the first declaration in 1944 in Turkey, Bluetongue infection incursions have been reported by numerous investigators $(5,8,14,23,31,33)$. Seroprevalence of BTV infection in cattle of South, southeast and Aegean regions of Turkey was detected as between 0$52.1 \%$ in convalescence serum samples by Burgu et al (5).

The most recent isolation studies revealed presence of the different serotypes in Turkey. The virus isolated in 1999 in European Turkey has been identified as BTV-9. Mellor and Witthmann (24) reported that BT infection has been circulating within Southern and Western Anatolia and BTV-16 has been isolated in Aegean region during the epidemic of 2000. Recently, BTV outbreaks were officially declared in Bulgaria, Greece (mainland and Aegean islands), Italy, and Portugal (24). So far, presence of four BTV serotypes (BTV-2, BTV-4, BTV9, BTV-16) has been reported in Turkey $(8,24)$.

Akabane disease which causes abortion, fetal mummification, stillbirths and arthrogripposis/ 
hydranencephalie complex in ruminant species $(17,19)$ was serologically detected in one $(0.7 \%)$ animal in Kirklareli.

The occurrence of ephemeral fever in basis European Turkey provinces (i.e. Edirne, Kirklareli, Tekirdag, Istanbul, Canakkale) were detected as $15.3 \%$, $13 \%, 6.6 \%, 2.8 \%$ and $2.5 \%$, respectively. The overall seroprevalence of the disease was $8.04 \%$ in the region. This results showed that BEF has higher occurrence than AKA in the region.

By means of this study, valuable data were obtained on some Culicoides-born virus disease of ruminants. These data leaded to figure out the occurrence of BT, AKA and BEF in province basis of Thrace. Results indicated that high prevalance of BTV infection may reflect the presence of novel serotypes of BTV in the region. The well-known features of the disease, such as plurality and persistency in cattle may complicate local attempts to eradicate and/or control the disease (18).

Preventive approaches based on the fight with vector midges are accepted as to be non-practical and unsuccessful $(15,16)$. Because Turkey has an adequate geographic position and climatic feature, various vectorborne exotic diseases able to invade the country from its neighboring countries. Thus, animal health records showed that Culicoides-borne infections, (e.g. Bluetongue, Akabane, Ephemeral Fever) have often occured due to satisfactory environmental conditions in West, South and Southeastern Turkey.

One of the important features of the Bluetongue infection is plurality of the virus and outbreaks caused by several serotypes of the virus could be detected in the same region. The most valuable protective and control measurement against BT is effective vaccination. However, presence of several serotypes in country should take into consider in both preparation and administration of the vaccine as there is no close antigenic relation between BTV serotypes. Therefore, successful protection against BT can be achieved by using polyvalent vaccines included of local BTV serotypes.

\section{References}

1. Anonim. Bluetongue in Bulgaria: follow-up report No 1 . OIE Disease Information 2001a, 14, 230-231.

2. Anonim. Bluetongue in Greece: follow-up report No 2. OIE Disease Information 2001b, 14, 262-265.

3. Anonim. Bluetongue in Greece: typing of virus strains isolated in 1998-1999. OIE Disease Information 2000, 13, 33-34.

4. Billinis C, Koumbati M, Spyrou V, Nomikou K, Managa O, Panagiotidis CA, Papadopoulos O (2001): Bluetongue virus diagnosis of clinical cases by a duplex
RT-PCR: a comparison with conventional methods. J Virol Meth, 98, 77-89.

5. Burgu İ, Urman HK, Akça Y, Yonguç A, Mellor PS, Hambling C (1992): Serologic survey and vector surveillance for bluetongue in southern Turkey. 168-174. In: Bluetongue, African Horse Sickness and Related Orbivirusus. TE Walton, BI Osburn (Eds), Crs. Press Inc, Boca Raton, Fla.

6. Davies SS, Gibson DS, Clark R (1984): The effect of bovine ephemeral fever on milk production. Aust Vet J, 61, 128-129.

7. Dik B (1997): Ceratopogonid'ler ve parazitolojik önemleri. Parazitoloji'de Arthropod Hastalıkları ve Vektörler. Ed, A Özcel, N Daldal, Türkiye Parazitoloji Derneği, 13, 111-143.

8. Ertürk A (1994): Çeşitli serumlarda (koyun, keçi, sığır) mavidil antikorlarinin agar-jel presipitasyon testi ile araştırılması. Etlik Vet Mikrobiol Derg, 7, 1-19.

9. Frey HR, Liess B (1971): Vermehrungskinetik und verwendbarkeit eines stark zytopathogenen VD-MD virusstammes für diagnostische untersuchungen mit der mikrotiter-methode. Zbl Vet B, 18, 61-71.

10. Gibbs EP and Greiner EC (1994): The epidemiology of bluetongue. Comparative Immunology, Microbiology and Infectious Disease, 17, 207-220.

11. Goldsmit L, Barzilai E, Tarmor A (1975): The comparative sensitivity of sheep and chicken embrios to bluetongue virus and observations on viremia in experimentally infected sheep. Aust Vet J, 51, 190-196.

12. Gorman BM (1990): The bluetongue viruses. Curr Top Microbiol Immunol, 162, 1-19.

13. Hawkes RA (1996): The Global distrubution of bluetongue. 6-14. Proceeding of the first Southeast Asia and Pasific Regional Bluetongue Symposium. Kunming, August 22-24.

14. Hazıroğlu R (1987): Buză̆ılarda Hydranencephalie Olgularında Patolojik-Anotomik Bulgular. Doktora Tezi, Ankara Üniversitesi Sağlık Bilimleri Enstitüsü, Ankara.

15. Inaba Y, Matumoto M (1981): Congenital arthrogryphosishydranencphaly syndrome. 653-671. In:Virus Disease of Food Animales. EPJ Gibbs (Ed), Academic Press, London.

16. Inaba Y, Matumoto M (1990): Akabane virus. 467-480. In: Virus Infection of Ruminants. Z Dinter, B Morein, Amsterdam (Eds), The Netherland.

17. Jagoe S, Kurkland PD, Harper P (1993): An outbreak of Akabane virus induced abnormalities in calves after againstment in an endemik region. Aust Vet J, 70, 56-58.

18. Kimberling CV (1988): Akabane disease. 71-72. In: Jensen And Swift's Diseases of Sheep. 3th ed.

19. Kirkland PD, Barry RD, Harper PAW, Zelski RZ (1988): The development of Akabane virus-induced congenital abnormalities in cattle. Vet Rec, 122, 582-586.

20. Konno S, Moriwaki M, Nakagava M (1982): Akabane disease in cattle. congenital abnormalitis caused by viral infection. Spontaneous disease, Vet Pathol, 19, 246-266.

21. Konno S, Nakagava M (1982): Akabane disease in cattle: congenital abnormalitis caused by viral infection. Experimental disease, Vet Pathol, 19, 267-279. 
22. Luedke AJ, Jochim MM (1977): Bluetongue in cattle: effects of Culicoides variipennis transmitted bluetongue virus on pregnant heifers and their calves. Am J Vet Res, 38, 1687-1695.

23. Mellor PS, Jennings DM, Hambling C, Burgu I, Urman HK, Akça Y, Hazıroğlu R, Alkan F, Yonguç AD, Özkul A, Eren H (1995): Control of Akabane disease and surveillance of bluetongue and ephemeral fever. 24. United Nations Development Programme, Food and Agriculture Organization of the United Nations, Rome. Mellor PS, Wittmann EJ (2002): Bluetongue virus in the mediterranean basin 1988-2001. Vet J, 164, 20-37.

25. Mertens PPC (1990): Orbiviruses and Coltiviruses. 10431061. In: Encylopedia of Virology, Ed, A Granoff, RG Webster, Vol, 2, Harcourt Sience and Technology Comp, Academic Press, San Diego, California, USA.

26. Murphy FA, Gibbs JEP, Horzineck CM, Studdent MJ (1999): Veterinary Virology, $3^{\text {th }}$ ed., Raven Press Ltd, New York, USA.

27. Osburn BI, Mc Gowan B, Heron B, Loomis E, Bushnell R, Stott JL, Utterback W (1981): Epizootiologic study of bluetongue: virological and serological results. Am J Vet Res, 42, 884-887.

28. Parsonson IM, Snowdown WA (1973): Experimental infection of pregnant cattle with ephemeral fever virus. Aust Vet J, 50, 335-337.
29. Roy P (2002): Orbivirus. 957-963. CD Tidona, G Darai (Eds). The Springer Index of viruses. Springer-Verlag, Berlin, Germany.

30. Theodoridis A, Giesecke WH, Du Toit IJ (1973): Effect of ephemeral fever on milk production and reproduction of dairy cattle. Ond J Vet Res, 40, 83-91.

31. Urman HK, Milli Ü, Mert N, Berkin S, Kahraman MM, Yüce H, Avvuran H (1979): Türkiye'de buzağılarda konjenital epizootik arthrogriphosis ve hydranencephalie olayları. Ankara Üniv Vet Fak Derg, 26, 287-292.

32. Walton TE (1992): Akabane. 72-75. In: Veterinary Diagnostic Virology. AE Castro (Ed), WP Heuschele, Boston.

33. Yonguç AD, Taylor WP, Csonton L, Worrall E (1982): Bluetongue in western Turkey. Vet Rec, 111, 144-146.

Geliş tarihi: 18.10.2006 / Kabul tarihi: 27.11.2006
Address for correspondance
Taner Karaoglu, DVM, PhD.
Ankara University, Faculty of Veterinary Medicine,
Department of Virology.
Diskapı 06110 Ankara - Turkey
e-mail:karaoglu@veterinary.ankara.edu.tr 